\title{
Poverty Effects of Minimum Wage Increase in Nigeria
}

\author{
Akin-Olagunju, O.A.* Akinribido, B. Yusuf, S.A. \\ Department of Agricultural Economics, University of Ibadan, Nigeria
}

\begin{abstract}
This paper examined the influence of Minimum wage (MW) increase on poverty level of households whose heads were in formal employment and the spillover effect on those in informal employment. It assessed distribution of real per capita household expenditure (PCPHE) and real monthly wage of workers in the two sectors. Fuzzy set approach was used to estimate multidimensional poverty (MDP) index of the population which served as poverty line and the poverty rate of households which was utilized as regressand in Instrumental Variable (IV) regression, with real monthly wage as key regressor. The study also estimated MW coverage and percentage of low-wage earners in poor and non-poor households. The results showed that PCPHE did not reflect wage gains observed after MW increase in the sectors but there was slight reduction in poverty level. Formal sector workers were poorer than those in informal sector and poverty worsened for public sector employees after MW increase compared to employees in private sector. The implication of the result is that MW should not be the sole redistributive policy in the formal sector and its increase should only form part of a comprehensive national economic development strategy.
\end{abstract}

Keywords: Employment, fuzzy set, instrumental variable, minimum wage, multidimensional poverty.

DOI: $10.7176 / \mathrm{DCS} / 9-11-03$

Publication date: November $30^{\text {th }} 2019$

\section{Introduction}

\subsection{Background of the study}

Minimum wage (MW) legislation is one of the policy tools usually adopted by governments of developing countries to fight poverty, redistribute income and help the vulnerable (Pauw and Leibbrandt, 2012). It is meant to help the workers at the lowest rung of wage earning so that they can also have decent living. Although some researchers have criticized $\mathrm{MW}$ as a poverty-reducing tool claiming that it leads to job losses, diverts attention from other important public policies and has poor target efficiency (Sabia, 2014). However, developing countries might present some exceptions especially on the ground that social protection policy is virtually non-existent for workers (Sugiyarto and Endriga, 2008). More so, it is possible for MW to still have substantial benefit on the families it does impact on even if it is poorly targeted (Acs et al., 2014).

In Nigeria, MW policy in the formal sector dates to 1955 and there had been a total of thirteen (13) commissions set up to look into issues concerning workers' pay (Aminu, 2011). In recent times, several significant reviews have been made because of agitations by the labour unions for a pay that is commensurate with economic situation (Anake et al., 2014). The administration of General Abdul Salami Abubakar announced a new MW increase which was to take effect from September 1998. State governments and formal private employers were mandated to pay $\$ 3,000.00$ as the minimum monthly take home pay of workers while the Federal government was to pay $\$ 3,500.00$. This was later reviewed to $\$ 5,500.00$ (states and private) and $\$ 7,500.00$ (federal) by the administration of President Olusegun Obasanjo, with effective date from 1st May, 2000. In 2011, the administration of President Goodluck Jonathan legislated that $\$ 18,000.00$ be paid to all workers in both public and private sectors.

\subsection{Problem statement}

Despite large resource endowments, poverty in Nigeria is pervasive and is compounded by unequal access to opportunities and infrastructures (Omonona, 2009) with poverty assessments showing similar trends whether from unidimensional or multidimensional perspectives (Oyekale and Oyekale, 2013). Minimum Wage (MW) has also not been well structured to cater for the needs of the workers and this has made continuous agitation seemingly inevitable and the multiplier effects unclear (Nwude, 2013). Price increases also continue to eat deep into the per capita earnings of the workers (Fapohunda et al., 2013; Akpasung, 2014). Thus, Nigerian workers are in a pitiable state when their earnings and living conditions are compared with their counterparts in other developing nations (Anake et al., 2014).

Employees in developing countries usually work very hard to fight their way out of poverty but the earnings are not enough to ensure decent living for themselves and their dependants (World Bank, 2012). This calls for several avenues to assist workers, one of which is the MW policy in the formal sector ${ }^{1}$ aimed at raising the pay of

\footnotetext{
${ }^{1}$ Informal sector workers are usually left out of MW in many developing countries and were just included in South Africa's MW legislation in 2002 (Dinkelman and Ranchhod, 2012). Definition of informality varies by countries and authors. In the developed world, one of the criteria of informality is the absence of social security for a worker while in developing world informality has been linked to small scale businesses,
} 
low-wage earners (Alaniz et al., 2011). In Nigeria, MW had been adjusted upwards several times to keep pace with the economic realities. However, despite the increases, workers' welfare seems not to have been taken care of which is seen in unending agitation for more increases thus necessitating this study. In addition, masses bear the brunt with unending increases in the prices of essential goods by informal sector workers in the effort at replicating better conditions in the sector. There is thus the need to ascertain if MW has brought about the intended benefit of poverty reduction for the formal sector (covered) workers and what has been the effect on the informal sector (uncovered) workers.

\subsection{Research questions and objectives}

This study sought to answer the following research questions:

- What is the distribution of the percapita household expenditure (PCPHE) and real monthly wages of formal and informal sector workers pre- and post-MW increase?

- How has the households fared in terms of poverty rates?

- Has the MW increase been able to raise the target group out of poverty?

- What is the level of compliance of formal sector employers to the MW increase?

- What is the effect of MW on the poverty level of workers' households?

In line with the afore-mentioned, this study assessed the effect of MW increase on the poverty status of households whose heads engage in formal and informal employments. The specific objectives were to:

1. describe the distribution of PCPHE and real monthly wages of workers in both formal and informal employments before and after MW increase;

2. analyze the poverty rate of all households across employment categories and other socio-economic characteristics;

3. examine the level of coverage of MW for working heads in formal employment prior to wage increase and after the increase;

4. assess the level of compliance of public and private sector employers to the MW increase, and

5. determine the effect of MW and its increase on the poverty level of households.

\subsection{Justification}

This work is justified on the following grounds. At the international level, most works in the area of MW usually focus on employment effect (Pauw and Leibbrandt, 2012). Although lots of works on poverty effect of MW have been carried out globally in recent times, many researches focus on Latin America (Gindling, 2014; Kapelyuk, 2014). This work applies MW-poverty analysis to the Nigerian context. More so, empirical analysis of MW, with reference to poverty effects and its distribution, has received little attention in Nigeria. Studies on MW have focused on effect of MW increase on household food security (Ajani, 2006); impact of MW review on publicprivate wage differential (Aminu, 2011); politics of MW (Nwude, 2013); nature of MW implementation, the challenges and some suggestions for better impact (Fapohunda et al., 2013) and effect of MW increase on unemployment (Akpasung, 2014). Anake et al. (2014) analyzed the impact of MW on socioeconomic characteristics of workers but the study was not national and considered only low-income formal sector workers using primary data.

In the same vein, poverty analyses in Nigeria have focused mainly on income or expenditure (e.g Okunmadewa et al., 2007; Aigbokhan, 2008; Omonona, 2009). However, in recent times, research efforts have been geared towards multidimensional poverty (MDP). Oyekale and Okunmadewa (2008) assessed MDP in Abia State, Oyekale et al. (2009) decomposed MDP for rural Nigeria, Oyekale (2011) studied the impact of poverty reduction strategies on MDP in rural Nigeria, Salman (2012) evaluated the effect of microenterprises on poverty in Osun State while Oyekale and Oyekale (2013) considered MDP in Nigeria with Demographic and Health Survey (DHS) data. On the other hand, Sowunmi et al. (2012) adopted spatial approach to poverty analysis using senatorial district level data. This study is novel in its application of MDP approach to MW analysis using a nationallyrepresentative secondary data.

\subsection{Review of literature}

Several methodologies have been adopted by researchers in assessing the effect of MW on poverty, but econometric approach has been mostly used. These include the works of Neumark et al. (2006), Gindling and Terrell (2010), Kapelyuk (2014). Others such as Bird and Manning (2008), Pauw and Leibbrandt (2012) and Acs et al. (2014) utilized simulation method. In Nigeria, many works have also adopted econometric methods (e.g Ajani, 2006; Aminu, 2011 and Akpasung, 2014), but none has treated endogenous relationship between MW and poverty. This study adopts instrumental variable (IV) approach to treat endogeneity issue which is little attended to in MW-poverty literature (Neumark and Wascher, 2008 as cited in Kapelyuk, 2014). Finally, this work will

street trading and domestic work (Staneva and Arabsheibani, 2014). 
give government policy direction with respect to the effect of MW on formal and informal sector workers to stem the tide of agitations by the former and improve the welfare of the latter.

Numerous works have been carried out on the MW-poverty linkage and there are diverse results. Foguel et al. (2001), Gindling and Terrell (2010), Ham (2013) and Kapelyuk (2014) established poverty reducing effects of MW for the different countries studied. On the other hand, Neumark et al. (2006) pointed out that result of its study of the effect of MW on family income distribution in Brazil does not support the view that MW has any positive distributional effect to raise income of low wage-earning families. Pauw and Leibbrandt (2012) submitted that MW is a controversial policy tool going by the distributional problem discovered thus making it unsuitable as a poverty-reducing strategy. The negative effect covered both the rich and the poor. Some authors have even identified several channels through which MW affect poverty. In Nicaragua, Alaniz et al. (2011) came up with the finding that though higher MW led to poverty reduction among households, this depends on whether it is household head that is affected by the MW or not. Gindling (2014) submitted that whether increase in MW will increase or decrease poverty in developing countries depends on some factors. These are whether those covered by the MW policy loses jobs because of adjustment, how the MW affect those in the uncovered (informal) sector, whether the low-wage workers who are essentially the target group live in poor households, level of enforcement and presence or absence of social safety nets to cater for those negatively affected by the MW increase. The study concluded that increase in MW reduces poverty in developing countries, but the effect is modest due to the prevalence of uncovered informal sector workers.

On the effect of MW on the uncovered sector, the work of Gindling and Terrell (2005) in Costa Rica suggests that there is no impact on self-employment. Increase in MW merely raises wages of formal sector employees relative to the self-employed who are not covered by the MW. Alaniz et al. (2011) opined that MW could have indirect effect on the self-employment sector through absorption of workers pushed from formal sector which ultimately drives down wages in the uncovered sector. On the other hand, efforts of institutions (e.g unions) that try to replicate MW condition in the informal sector might eventually lead to poverty reduction (Gindling and Terrell, 2010). Higher paid informal employees also benefitted from the spillover from MW increase in the formal sector in Honduras (Ham, 2013).

\section{Materials and Methods}

\subsection{Data}

The study employed data from the General Household Survey (GHS) conducted by the National Bureau of Statistics (NBS). The GHS is usually collected in waves consisting of two periods (pre-planting and post-planting) each. This study made use of post-planting data from the 2010/11 and 2012/13 waves. The MW increase within the period was signed into law by the former President; Goodluck Jonathan in August 2010 but became effective in January 2011. The post-planting data for the first wave (Post-planting 2010) was collected around September and October 2010. This coincided with the pre-MW increase period. The post-harvest data for the first wave was collected around March 2011 which was just three months from the effective date of implementation of the wage increase. That round of data will not be appropriate for use in post-MW increase analysis because employers are usually reluctant to comply with the directive in the first few months (Aminu, 2011). Thus, the following round of data (i.e post-planting) collected around September and October 2012 was used for post-MW increase analysis.

\subsection{Analytical methods}

Fuzzy set approach was used to estimate the MDP rates for each household and the entire population of households. The rate for the population served as the poverty line while household poverty rate was used as the dependent variable in the regression analysis. Instrumental variable (IV) regression was implemented because of the possibility of endogenous relationship between the poverty rate and wage variable (Neumark and Wascher, 2008 in Kapelyuk, 2014). Generalised Method of Moments (GMM) approach was adopted due to the continuous nature of the poverty and wage variables and the fact that it is 'a mainstay of econometric practice' (Baum et al., 2007). The count of household assets, which were essentially non-productive assets, was used as instrument. It was suggested to correlate with wage because the higher the (wage) income, the higher the level of consumption of (normal) goods. On the other hand, household asset count was assumed to be uncorrelated with poverty rate since the rate is multidimensional in nature. The result diagnostics established the assumptions as plausible (see Table 7b). Self-employment and North East were used as reference categories because the self-employed were not covered by the MW policy while North East had the lowest level of MDP among other geopolitical zones (Oyekale et al., 2009; Oni and Adepoju, 2014).

2.2.1 Fuzzy set

According to Diallo (2012), fuzzy set theory approach to MDP was first proposed by Cerioli and Zani (1990) and was further developed by Dagum (2002), Dagum and Costa (2004) and Mussard and Pi Alperin (2005). Costa (2002) gives a mathematical exposition of the fuzzy set methodology. Given a population A of a household, A = $\left\{\mathrm{a}_{1}, \mathrm{a}_{2}, \ldots, \mathrm{a}_{\mathrm{n}}\right\}$, the subset of poor household $\mathrm{B}$ includes any household $a_{1} \in B$ which presents some degree of 
poverty in at least one of the $\mathrm{m}$ attributes. The degree of membership to the fuzzy set $\mathrm{B}$ of the $\mathrm{i}^{{ }^{-}}{ }^{\text {th }}$ household

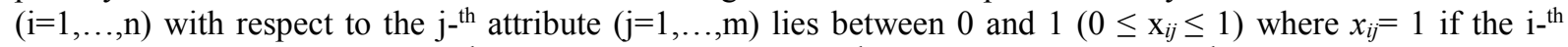
household does not possess the $\mathrm{j}_{-}{ }^{\text {th }}$ attribute and $x_{i j}=0$, if the $\mathrm{i}^{\text {th }}$ household possess the $\mathrm{j}^{-{ }^{\text {th }}}$ attribute. The MDP ratio of each household $\left(P_{i}\right)$ is given by,

$$
P_{i}=\sum_{j=1}^{m} x_{i j} w_{j} / \sum_{j=1}^{m} w_{j}
$$

Where $w_{j}$, is the weight attached to the $\mathrm{j}$-th attribute. It denotes the intensity of deprivation of $x_{j}$. Thus,

$$
w_{j}=\log \left[n / \sum_{i=1}^{n} x_{i j} n_{j}\right] \geq 0
$$

The MDP ratio of the population $\left(P_{I}\right)$ is captured with the formula,

$$
P_{I}=\sum_{i=1}^{n} P_{i} n_{i} / \sum_{i=1}^{n} n_{i}
$$

Unidimensional poverty ratio for each of the $\mathrm{j}$-th attribute can be gotten through the weighted average of $x_{i j}$ with weight $n_{i}$.

$$
P_{j}=\sum_{i=1}^{n} x_{i j} n_{i} / \sum_{i=1}^{n} n_{i}
$$

Another pathway for the estimation of the MDP ratio of the population is as follows,

$$
P_{I}=\sum_{i=1}^{n} P_{i} n_{i} / \sum_{i=1}^{n} n_{i}=\sum_{j=1}^{m} P_{j} w_{j} / \sum_{j=1}^{m} w_{j}
$$

The categories of poverty attributes used in deriving MDP level range from financial, productive and household assets, to education, food security and household expenditure. These variables address some of the functioning and capabilities of households in harnessing resources to combat poverty.

\subsection{Model specification}

For the assessment of the effect of wage on poverty rate, the following linear function was specified,

$$
P_{i}=f\left(W_{i}\right)
$$

$P$ is poverty rate of household $i$, and $W$ is the monthly wage of head of household $i$.

The linear regression model in GMM specification can be written as,

$$
Y_{i}=X_{i}^{\prime} \beta+\varepsilon_{i}
$$

Combining insights from Greene (2003), Baum (2007) and Hansen (2015), the empirical moment equation is given as,

$$
\left[\frac{1}{N} \sum_{i=1}^{N} Z_{i}\left(Y_{i}-X_{i}^{\prime} \hat{\beta}\right)\right]=\left[\frac{1}{N} \sum_{i=1}^{N} m_{i}(\hat{\beta})\right]=\bar{m}(\hat{\beta})=0
$$

$\bar{m}$ is the $\ell$-vector and each $\ell$-moment equation is a sample moment which is averaged over $\mathrm{N}$. The GMM estimator for $\hat{\beta}$ is thus the parameter value that solves $\bar{m}(\hat{\beta})$ for zero. If $\ell=K$, there is exact solution to the empirical moment equation, otherwise there is over-identification (if $\ell>K$ ) and under-identification (if $\ell<K$ ) in which case it will be impossible to find solution and there won't be a unique solution respectively. $Y_{i}=$ Dependent variable, which is the MDP index of $\mathrm{i}$-th household $\left(0 \leq Y_{i} \leq 1\right)$

$X_{i}=$ Vector of explanatory variables; $\beta=$ vector of coefficients; $\varepsilon_{i}=$ stochastic error term $\bar{m}(\hat{\beta})=$ empirical moment equation; $\quad \ell=$ number of moment conditions;

$K=$ number of parameters; $Z_{i}=$ instruments; $\quad \hat{\beta}=$ parameters vector

The explanatory variables are as follows,

$X_{1}=$ Location of household (rural $=1$, urban $=0$ )

$X_{2}=$ Sex of the household head (female $=1$, male $=0$ )

$X_{3}=$ Marital status of the household head (married $=0$, otherwise $=1$ )

$X_{4}=$ Literacy of head (illiterate $=1$, literate $=0$ )

$X_{5}=$ Household size

$X_{6}=$ Age of household head (years)

$X_{7}=$ Age squared

$X_{8}=$ Log of monthly wage

$X_{9}=$ Ownership of uncultivated land $(\mathrm{No}=1, \mathrm{Yes}=0)$

Employment categories of household heads dummies

$X_{10}=$ Self-employed $\quad X_{11}=$ Private sector employment $X_{12}=$ Public sector employment

Geopolitical zones (GPZ) dummies

$$
X_{13}=\text { North-East (NE) } \quad X_{14}=\text { North-West (NW) } \quad X_{15}=\text { North-Central (NC) }
$$

$X_{16}=$ South-West (SW) $\quad X_{17}=$ South-East (SE) $\quad X_{18}=$ South-South (SS)

Each of the employment categories and GPZ dummies was specified thus: $\mathrm{D}=1$ if Yes, 0 otherwise.

\section{Results}

The descriptive statistics of household characteristics (Table 1) showed that majority of the households reside in rural areas, were headed by the married, males and those engaged in self-employment. 
Table 1: Descriptive statistics of household head characteristics before and after MW increase.

\begin{tabular}{|c|c|c|c|c|c|}
\hline \multirow[t]{2}{*}{ Variable } & \multirow[t]{2}{*}{ Categories } & \multicolumn{2}{|c|}{$\begin{array}{c}\text { Before } \\
\mathrm{N}=3421\end{array}$} & \multicolumn{2}{|c|}{$\begin{array}{c}\text { After } \\
\mathrm{N}=3964\end{array}$} \\
\hline & & Frequency & Percentage (\%) & Frequency & Percentage (\%) \\
\hline Location of & Urban & 1,059 & 30.96 & 1,152 & 29.06 \\
\hline Household & Rural & 2,362 & 69.04 & 2,812 & 70.94 \\
\hline \multirow[t]{2}{*}{ Gender of head } & Male & 2,961 & 86.55 & 3,440 & 86.78 \\
\hline & Female & 460 & 13.45 & 524 & 13.22 \\
\hline \multirow{4}{*}{$\begin{array}{l}\text { Marital status of } \\
\text { head } \\
\text { Literacy of head }\end{array}$} & Married & 2,800 & 81.92 & 3,267 & 82.44 \\
\hline & Otherwise & 618 & 18.08 & 696 & 17.56 \\
\hline & Literate & 2,207 & 64.51 & 2,586 & 65.24 \\
\hline & Illiterate & 1,214 & 35.49 & 1,378 & 34.76 \\
\hline \multirow{3}{*}{$\begin{array}{l}\text { Employment } \\
\text { category of head }\end{array}$} & Self & 2,786 & 81.44 & 3,257 & 82.16 \\
\hline & Private & 225 & 6.58 & 251 & 6.13 \\
\hline & Public & 410 & 11.98 & 456 & 11.50 \\
\hline \multirow{8}{*}{$\begin{array}{l}\text { Land } \\
\text { status } \\
\text { Zone }\end{array}$} & Yes & 1,329 & 38.85 & 687 & 17.33 \\
\hline & No & 2,092 & 61.15 & 3,277 & 82.67 \\
\hline & North Central & 513 & 15.00 & 694 & 17.51 \\
\hline & North East & 578 & 16.90 & 651 & 16.42 \\
\hline & North West & 724 & 21.16 & 810 & 20.44 \\
\hline & South East & 554 & 16.19 & 609 & 15.36 \\
\hline & South South & 478 & 13.97 & 595 & 15.01 \\
\hline & South West & 574 & 16.78 & 605 & 15.26 \\
\hline
\end{tabular}

Distributions of percapita household expenditure (PCPHE) and monthly wages of household heads by deciles are presented in Tables 2 and 3, respectively. Average PCPHE decreased with MW increase for all employment categories across all deciles except for public sector employees that had very small increase at the 10th decile. Real monthly wage increased significantly for public sector employees across all deciles after MW review. On the other hand, the gains for household heads in private sector was minimal (1st -3 rd deciles), reduced (4th -5 th deciles) and increasing from the 6th decile to reach its highest at the 10th decile. For the self-employed household heads, real monthly wage almost doubled for $1 \mathrm{st}-5$ th deciles, there were very substantial increases for 6 th -9 th deciles but substantial reduction at the 10th decile, after MW increase.

Table 2: Distribution of household percapita expenditure (PCPHE) (2009 prices)*.

\begin{tabular}{|c|c|c|c|c|c|c|}
\hline \multirow{4}{*}{$\begin{array}{c}\quad N= \\
\text { Decile }\end{array}$} & \multicolumn{3}{|c|}{ Before wage increase } & \multicolumn{3}{|c|}{ After wage increase } \\
\hline & Self & Private & Public & Self & Private & Public \\
\hline & 2786 & 225 & 410 & 3257 & 251 & 456 \\
\hline & \pm & 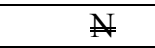 & 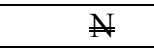 & 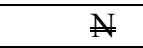 & 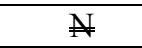 & 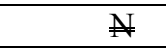 \\
\hline 10 & 98.47 & 201.61 & 228.76 & 80.45 & 139.29 & 156.48 \\
\hline 20 & 206.09 & 379.50 & 396.02 & 161.70 & 269.07 & 312.41 \\
\hline 30 & 294.52 & 535.63 & 519.96 & 225.64 & 383.71 & 414.63 \\
\hline 40 & 379.68 & 705.87 & 666.43 & 297.60 & 485.64 & 542.56 \\
\hline 50 & 474.62 & 824.82 & 838.74 & 370.33 & 591.02 & 681.82 \\
\hline 60 & 594.63 & $1,014.18$ & $1,032.16$ & 451.63 & 712.96 & 815.33 \\
\hline 70 & 727.75 & $1,234.51$ & $1,257.19$ & 555.12 & 884.49 & 978.89 \\
\hline 80 & 906.38 & $1,601.29$ & $1,545.16$ & 694.89 & $1,104.41$ & $1,246.19$ \\
\hline 90 & $1,168.26$ & $2,182.43$ & $1,973.33$ & 931.69 & $1,425.85$ & $1,659.98$ \\
\hline 100 & $2,105.67$ & $3,410.82$ & $3,266.85$ & $1,737.33$ & $2,315.39$ & $3,284.38$ \\
\hline
\end{tabular}

${ }^{*}$ Consumer Price Indices (CPI) are from Central Bank of Nigeria (2012). 
Table 3: Distribution of household head monthly income (in 2009 prices).

\begin{tabular}{crrrrrr}
\hline & \multicolumn{3}{c}{ Before } & \multicolumn{3}{c}{ After } \\
\cline { 2 - 7 }$N=$ & Self & Private & Public & Self & Private & Public \\
Decile & 1090 & 201 & 399 & 1213 & 222 & 437 \\
\hline 10 & 341.72 & 668.13 & $5,845.01$ & 621.00 & 773.43 & $7,803.86$ \\
20 & 827.86 & $2,276.71$ & $10,662.81$ & $1,501.09$ & $2,311.03$ & $15,015.11$ \\
30 & $1,574.58$ & $5,043.78$ & $14,709.94$ & $2,845.33$ & $5,146.90$ & $19,625.30$ \\
40 & $2,539.13$ & $7,879.38$ & $18,609.63$ & $4,737.28$ & $7,570.39$ & $24,284.07$ \\
50 & $4,149.73$ & $11,536.78$ & $23,588.53$ & $7,614.32$ & $11,468.33$ & $29,919.63$ \\
60 & $7,167.53$ & $15,586.69$ & $28,180.58$ & $11,750.47$ & $16,107.21$ & $37,148.54$ \\
70 & $10,681.41$ & $19,119.96$ & $35,372.99$ & $15,976.01$ & $22,066.88$ & $46,487.02$ \\
80 & $16,345.11$ & $27,084.06$ & $43,616.90$ & $22,223.26$ & $29,927.20$ & $57,395.90$ \\
90 & $28,824.37$ & $38,572.68$ & $61,036.30$ & $33,930.57$ & $44,971.33$ & $81,124.22$ \\
100 & $211,021.22$ & $100,346.09$ & $119,724.24$ & $175,240.58$ & $136,234.78$ & $188,766.85$ \\
\hline
\end{tabular}

The breakdown of the MDP situation of households is given in Table 4. Households headed by females, the unmarried and illiterates were poorer than their respective counterparts even with MW increase. Across the zones, SS was the poorest zone while NW was the least poor pre-MW. With MW increase, SE became the poorest while NE was least poor. The North seems to fare better than the South in terms of MDP. Over the two (2) periods, MDP increased in SE $(5.06 \%)$ and NW $(0.29 \%)$, while it decreased in the other zones (Table 4). The MDP by employment categories generally decreased by a minimum of $2.04 \%$ across zones, as a result of introduction of MW. This was more pronounced in the private sector. However, in the SE, poverty rate increased both in the private and self-employment sectors. Households residing in urban areas were multi-dimensionally poorer than households in rural areas even after MW increase.

Table 4: Poverty rate for socioeconomic groups across employment categories (\%).

\begin{tabular}{|c|c|c|c|c|c|c|c|c|c|}
\hline \multirow{2}{*}{\multicolumn{2}{|c|}{ Socioeconomic characteristics }} & \multicolumn{2}{|c|}{ Self } & \multicolumn{2}{|c|}{ Private } & \multicolumn{2}{|c|}{ Public } & \multicolumn{2}{|c|}{ All } \\
\hline & & Before & After & Before & After & Before & After & Before & After \\
\hline \multirow[t]{2}{*}{ Location } & Urban & 14.21 & 14.74 & 15.84 & 14.25 & 10.59 & 9.81 & 13.71 & 13.72 \\
\hline & Rural & 12.70 & 12.31 & 14.79 & 13.43 & 10.30 & 9.41 & 12.57 & 12.12 \\
\hline \multirow[t]{2}{*}{ Gender } & Male & 12.57 & 12.18 & 15.10 & 13.83 & 10.41 & 9.52 & 12.48 & 11.97 \\
\hline & Female & 16.08 & 17.04 & 20.50 & 15.65 & 10.81 & 10.67 & 15.79 & 16.59 \\
\hline \multirow{4}{*}{$\begin{array}{l}\text { Marital } \\
\text { status } \\
\text { Literacy }\end{array}$} & Married & 12.64 & 12.13 & 14.80 & 13.63 & 10.42 & 9.50 & 12.79 & 11.91 \\
\hline & Otherwise & 15.02 & 16.33 & 18.38 & 15.38 & 10.54 & 10.37 & 14.83 & 15.76 \\
\hline & Literate & 11.21 & 11.22 & 14.89 & 13.26 & 10.29 & 9.42 & 11.38 & 11.09 \\
\hline & Illiterate & 15.68 & 15.32 & 19.79 & 20.07 & 13.60 & 13.82 & 15.74 & 15.38 \\
\hline \multirow[t]{7}{*}{ Zone } & North Central & 12.95 & 11.59 & 16.14 & 13.19 & 11.15 & 9.57 & 12.89 & 11.39 \\
\hline & North East & 12.40 & 10.36 & 15.80 & 11.79 & 9.11 & 7.73 & 12.04 & 10.04 \\
\hline & North West & 10.79 & 11.21 & 11.47 & 12.25 & 8.86 & 7.77 & 10.65 & 10.94 \\
\hline & South East & 14.09 & 19.15 & 13.28 & 19.54 & 9.82 & 13.96 & 13.63 & 18.69 \\
\hline & South South & 16.43 & 13.53 & 16.58 & 12.31 & 11.94 & 9.95 & 15.55 & 12.83 \\
\hline & South West & 13.84 & 12.58 & 15.73 & 13.78 & 11.28 & 9.96 & 13.86 & 12.48 \\
\hline & All & 13.09 & 12.90 & 15.44 & 13.91 & 10.44 & 9.62 & 13.19 & 12.96 \\
\hline
\end{tabular}

Whether wage increase will lead to poverty reduction depends on many factors one of which is the percentage of low-wage earners living in poor and non-poor households. The low-wage category encompasses those whose wages fall between the MW and twice the MW as stipulated by the authority (usually government) because they are the ones usually mostly affected by MW legislation (Kapelyuk, 2014). This is particularly applicable to Nigeria where the new MW hovers around two-folds of the initial amount ${ }^{1}$. The MDP status of households vis-à-vis the monthly wage of household heads covered by the MW legislation indicated that low-wage earners were more in the non-poor households (Table 5). For household heads that earn real MW and above ${ }^{2}$, prior to the wage increase, approximately one in every four of the low-wage household heads was in non-poor households while one in every five was found among the poor. After wage review, the low-wage heads increased to close to one in every two (non-poor households) and three in every ten (poor households).

\footnotetext{
${ }^{1}$ The MW before recent increase to $\$ 18,000.00$ was $\$ 7,500.00$ (federal). At 2009 prices, this is equivalent to $¥ 6,567.43$ (old) and $¥ 12,756.91$ (new).

${ }^{2}$ Household heads that earned below MW constituted $13.5 \%$ (before wage increase) and 22.3\% (after wage increase) of total household heads working in the formal sector, taking the federal-level MW as benchmark. The federal MW level was used as benchmark for the following reasons: (a) some states were paying more than the federally-legislated amount (b) in order not to over-state the poverty situation (c) it allowed meaningful comparison since the latest increase was the same across all tiers of (formal) employment.
} 
Table 5: Percentage of low-wage heads by MDP status* of households.

\begin{tabular}{lcc}
\hline & $\begin{array}{c}\text { Before wage } \\
\text { increase (\%) }\end{array}$ & $\begin{array}{c}\text { After wage } \\
\text { Increase (\%) }\end{array}$ \\
\hline a. Considering heads earning MW and above & & \\
\hline Low-wage household heads in poor households & 20.39 & 30.23 \\
Low-wage household head in non-poor household & 25.47 & 47.20 \\
\hline b. Including those that earn less than MW & & 42.43 \\
\hline Low-wage household heads in poor households & 28.03 & 65.26 \\
\hline
\end{tabular}

*Poverty line: 13.19\% (2010 - Before wage increase); 12.96\% (2012 - After wage increase)

Workers in the private sector that earned below MW were one-third and about half of total private sector employees before and after MW increase respectively as shown in Table 6 . On the other hand, the figure was very low in the public sector. Implicitly, there was the level of compliance with MW in the private sector of $52.3 \%$ after the wage increase. This was very low compared with public sector of $90.6 \%$. Although, compliance in the two sectors was worse off with wage increase, the negative change in the level of compliance was more for the private sector $(-16.4 \%)$ than the public sector $(-4.9 \%)$.

Table 6: Level of compliance in sectors (\%).

\begin{tabular}{lccc}
\hline & & Before wage increase & After wage increase \\
\hline Private & Earning below MW & 31.3 & 47.7 \\
& Compliance level & 68.7 & 52.3 \\
\hline Public & Earning below MW & 4.5 & 9.4 \\
& Compliance level & 95.5 & 90.6 \\
\hline Formal & Earning below MW & 13.5 & 22.3 \\
& Compliance level & 86.5 & 77.7 \\
\hline Informal & Get earnings below MW & 53.3 & 56.6 \\
\hline
\end{tabular}

The results of the IV 2-stage GMM regression are shown in Tables $7 \mathrm{a}$ and $\mathrm{b}$. Prior to MW increase, all the variables were significant with the exception of location, marital status and NC/SE dummies. Out of the significant variables, coefficients of literacy, household size, age, land ownership, private/public employment dummies and $\mathrm{SS} / \mathrm{SW}$ dummies were positively related to poverty rate while coefficients of gender, age squared, log of real wage and SE dummy showed negative relationship. After increase in MW, coefficients of marital status, literacy, household size, log of wage, land ownership, employment dummies and all GPZ dummies, with the exception of SS dummy, were significant. Coefficients of literacy, household size, land ownership, employment dummies and SE dummy varied positively with MDP index while others were negative. Variables like location of household, sex of household head, age, age squared and SS dummy were not significant.

Poverty increased with non-literate heads of households both pre and during MW. The results further revealed that the large households increased poverty level in the two periods. The coefficient of the age variable while that of the coefficient of age squared had negative sign. For the wage variable, $1 \%$ increase in log of wage reduces poverty rate by $4.18 \%$ (before MW increase) and 5.08\% (after MW increase). Land ownership was significant for the two periods and its non-possession aggravated poverty. Households whose heads engaged in private and public employments showed higher MDP compared to those in self-employment. Households having heads in public employment exhibited more poverty than those in private sector with wage increase. With respect to the reference category (NE), poverty rate was lower in NW but higher in SS and SW before MW increase while it was lower in NC, NW and SW but higher in SE after increase.

Diagnostic tests results showed the suitability of the instrumental variable and the endogeneity of the wage variable. The null hypotheses of under-identification and over-identification of instruments were rejected. For the weak identification test, Cragg-Donald Wald F-statistics was higher than the Stock-Yogo critical test values. All these results pointed to the fact that the model was exactly identified. The implication is that the excluded instrument (household asset count) was correlated with the endogenous regressor (log of real wage) which showed the relevance of the instrumental variable. The significance of the endogenous test also meant that real wage was rightly treated as an endogenous variable. 
Table 7a: Effect of real monthly wage on poverty rate.

\begin{tabular}{|c|c|c|c|c|c|c|}
\hline \multicolumn{7}{|c|}{ Instrumental variables (GMM) regression } \\
\hline Dependent variable: & Poverty rate & Bef & & & & After \\
\hline Explanatory var. & Coefficient & $\begin{array}{l}\text { Standard } \\
\text { error }\end{array}$ & z-value & Coefficient & $\begin{array}{l}\text { Standard } \\
\text { error }\end{array}$ & z-value \\
\hline (Constant) & 0.4040 & 0.0565 & $7.15^{* * *}$ & 0.5300 & 0.0728 & $7.28^{* * *}$ \\
\hline Location & -0.0066 & 0.0053 & -1.24 & -0.0079 & 0.0055 & -1.42 \\
\hline Gender & -0.0187 & 0.0096 & $-1.95^{*}$ & -0.0151 & 0.0093 & -1.64 \\
\hline Marital status & -0.0096 & 0.0087 & -1.10 & -0.0155 & 0.0085 & $-1.82^{*}$ \\
\hline Literacy & 0.0377 & 0.0061 & $6.17^{* * *}$ & 0.0422 & 0.0062 & $6.99^{* * *}$ \\
\hline Household size & 0.0023 & 0.0010 & $2.44^{* *}$ & 0.0020 & 0.0009 & $2.35^{* *}$ \\
\hline Age & 0.0026 & 0.0011 & $2.47^{* *}$ & 0.0011 & 0.0011 & 1.02 \\
\hline Age squared & $-2.53 e-05$ & $1.01 \mathrm{e}-05$ & $-2.51^{* * *}$ & $-1.46 e-05$ & $1.02 \mathrm{e}-05$ & -1.42 \\
\hline Log_wage & -0.0418 & 0.0071 & $-5.86^{* * *}$ & -0.0508 & 0.0084 & $-6.08^{* * *}$ \\
\hline Land ownership & 0.0107 & 0.0055 & $1.94^{*}$ & 0.0382 & 0.0073 & $5.26^{* * *}$ \\
\hline \multicolumn{7}{|l|}{ Employer } \\
\hline Private & 0.0362 & 0.0084 & $4.31^{* * *}$ & 0.0181 & 0.0072 & $2.53^{* *}$ \\
\hline Public & 0.0282 & 0.0112 & $2.53^{* * *}$ & 0.0436 & 0.0126 & $3.46^{* *}$ \\
\hline \multicolumn{7}{|l|}{ Zone } \\
\hline North Central & 0.0132 & 0.0101 & 1.30 & -0.0204 & 0.0092 & $-2.22^{* *}$ \\
\hline North West & -0.0190 & 0.0096 & $-1.99^{* *}$ & -0.0370 & 0.0103 & $-3.61^{* * *}$ \\
\hline South East & -0.0080 & 0.0094 & -0.85 & 0.0388 & 0.0079 & $4.92^{* * *}$ \\
\hline South South & 0.0547 & 0.0099 & $5.53^{* * *}$ & 0.0052 & 0.0065 & 0.81 \\
\hline South West & 0.0218 & 0.0095 & $2.31^{* *}$ & -0.0348 & 0.0090 & $-3.51^{* * *}$ \\
\hline
\end{tabular}

Significance level: $10 \%^{*}, 5 \%^{* *}, 1 \%{ }^{* * *}$

Table 7b: Instrumental Variable (IV) 2-stage GMM test statistics.

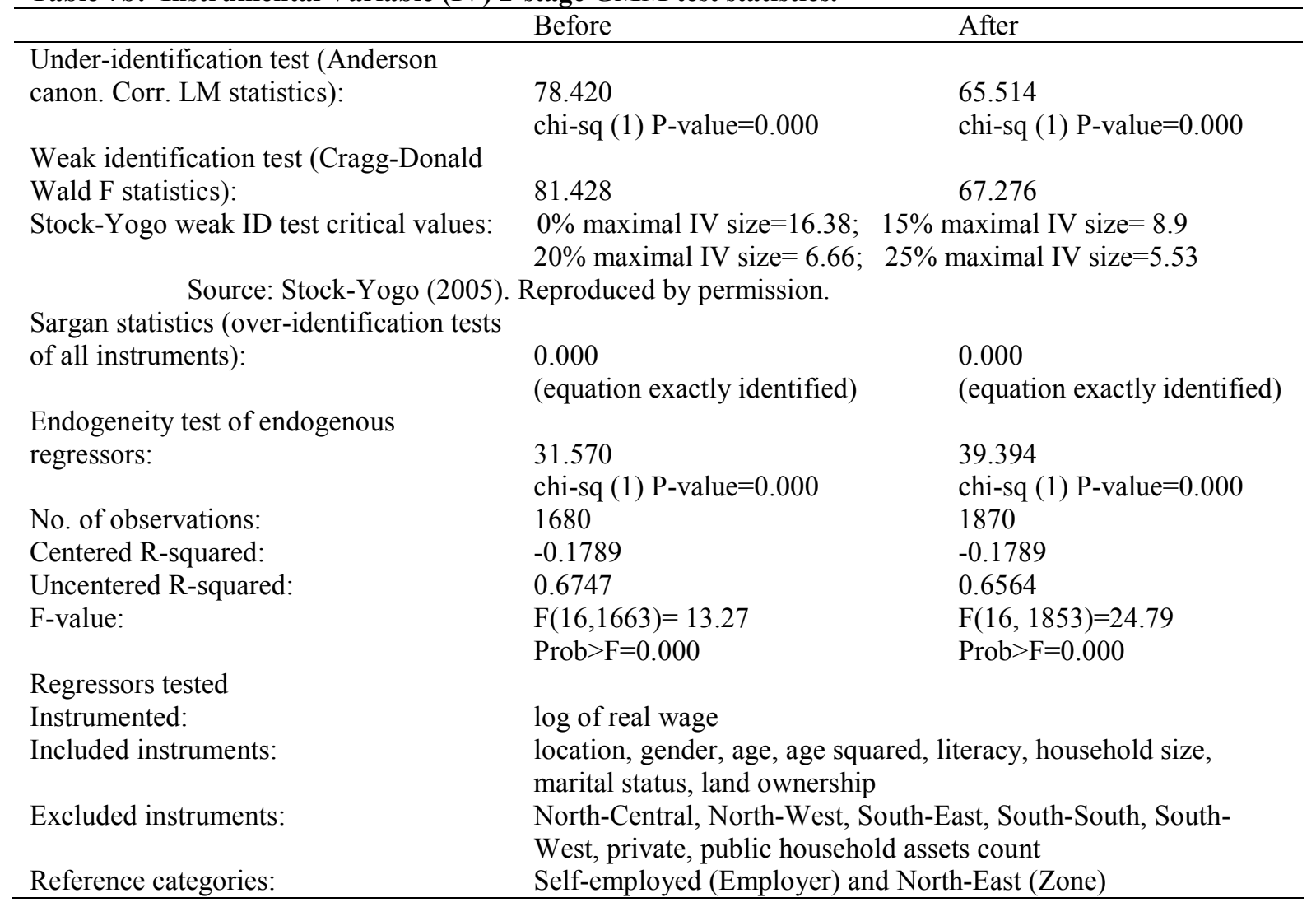

\section{Discussion}

The nature of the disparity in distribution of the real PCHE between public and private sectors indicated higher 
pay and better coverage for the public sector. Comparison with the self-employed showed that MW increase had significantly positive effect on self-employed heads at the lower deciles of wage distribution though they are not covered by the MW legislation. This supports reports by Alaniz et al. (2011) and Ham (2013) that MW could have spillover effect on the self-employed. The similar patterns of distribution of PCPHE for private and public sector employees suggested that higher wage did not translate to higher PCPHE in the formal sector generally.

The overall MDP rate decreased with MW increase in line with the findings of Foguel et al. (2001) and Gindling and Terrell (2010). Furthermore, the fact that households residing in rural areas were found to be poorer than those in urban areas might not be unconnected with agrarian nature of rural areas where access to food and land may not be a problem. Similarly, rural areas enjoy better social cohesion and cooperation. The positive effect of wage increase in the formal sector was skewed in favour of the non-poor households. This has implications for poverty reduction goal of MW increase. More workers were earning below MW in the private sector indicates non-compliance, as noted by Saget (2001). The proportion of those earning below MW in formal sector was small compared to more than half of wage earners in the informal sector who fell within this category implying that MW, as a poverty-reduction tool, was a bit effective since it reached large number of formal sector employees.

Positive relationship of the age of household head with poverty rate but the rate declined after certain age in line with life-cycle hypothesis. Furthermore, it is intuitive that higher wages experienced across all sectors reduced poverty rate of households because more resources were available to purchase goods and services. For the land variable result, bearing in mind that the land implied in the study was the non-cultivated, its non-possession might be one of the factors responsible for low PCPHE because there was no opportunity of buffering households' income through its disposal in the event of economic hardship.

\section{Conclusion}

This study adopted a novel approach to undertake MW-poverty analysis. It examined how increase in MW in the formal sector affected MDP in both formal and informal sectors using two (2) waves of Nigerian GHS data. Instrumental variable regression (GMM approach) was used to deal with the suspected endogenous relationship between poverty rate and real monthly wage using household asset count as instrument. The overall MDP rate decreased and there were obvious wage gains in both formal and informal sectors which might have contributed to lowering poverty rate. Nonetheless, these did not manifest in the real PCPHE of the households. MW was revealed to be a bit effective as a policy tool because of its impact on large number of formal employees but the benefit was skewed in favour of non-poor households. Better level of compliance with the MW legislation was observed in the public sector than in the private sector. Higher MW however caused the compliance level to drop in both sectors with private sector being worse-hit. Majority of the self-employed were in agriculture ${ }^{3}$ and these workers were better-off than their formal sector counterparts. By extension, households in rural areas were multidimensionally less poor than those in urban areas with non-possession of productive asset aggravating poverty.

Informal sector remains the main employer of labour in Nigeria. Therefore, any programme that affects the self-employed positively will assist majority of households in the country ${ }^{4}$. By implication, developing agriculture will likely lift lots of people out of poverty. Funds provision need be concentrated in the informal sector since it is not covered by the MW law. While advocating for (better) monitoring of the level of compliance to MW legislation and periodic adjustments for inflation, MW should be combined with social safety nets for maximum impact and the economy should be grown for higher purchasing power so that the general welfare gains are not undermined by price changes.

\section{References}

Acs, G., Wheaton, L., Enchantegui, M., and Nichols, A. (2014). Understanding the implication of raising the minimum wage in the district of Columbia. Urban Institute, USA.

Aigbokhan, B.E. (2008). Growth, inequality and poverty in Nigeria. Economic Commission for Africa ACGS/MPAMS discussion paper No. 3, United Nations Economic Commission for Africa (UNECA), Addis Ababa, Ethiopia.

Ajani, O.I.Y. (2006). Effect of wage increase on household food consumption among health workers of the University College Hospital (UCH), Ibadan. Journal of Rural Economics and Development, 15(1):1-19.

Akpasung, A.O. (2014). An empirical assessment of the effects of minimum wage increases on unemployment during democratic governance in Nigeria. International Journal of Humanities and Social Science, 4(13): 8798.

Alaniz, E., Gindling, T.H., and Terrell, K. (2011). The impact of minimum wages on wages, work and poverty in

\footnotetext{
${ }^{3}$ Those engaged in agriculture were $66.2 \%$ and $66.4 \%$, pre- and post-MW increase respectively. Employees in both public and private employments also took agriculture as secondary activity.

${ }^{4}$ In $2010,69.0 \%$ of the households were in the rural areas, $87.8 \%$ of the households in the rural areas were headed by the self-employed and these self-employed heads constituted $60.6 \%$ of the total heads. For 2012 , the values were $70.9 \%, 88.1 \%$ and $62.5 \%$ in the order described above.
} 
Nicaragua. IZA discussion paper No 5702.

Aminu, A. (2011). Government wage review policy and public-private sector wage differential in Nigeria. AERC research paper 223, African Economic Research Consortium, Nairobi, Kenya.

Anake, A.F., Manyo, T.S., and Ajom, O.O. (2014). Impact of national minimum wage on low income workers in Calabar municipality, Nigeria. Developing Country Studies, 4(26): 28-36.

Baum, C.F. (2007). Instrumental variables estimation in Stata. Faculty Micro Resource Center, Boston College.

Baum, C.F., Schaffer, M.E., and Stillman, S. (2007). Enhanced routines for instrumental variables/generalized method of moments estimation and testing. The Stata Journal, 7(4):465-506.

Bird, K., and Manning, C. (2008). Minimum wage and poverty in a developing country: simulation from Indonesia's household survey. World Development, 36(5): 916-933.

Central Bank of Nigeria, CBN (2012). Annual Reports 2012, p. 324.

Costa, M. (2002). A multidimensional approach to the measurement of poverty: an integrated research infrastructure in the socio-economic sciences IRISS, working paper series no. 2002-05, 2-12.

Diallo, F.L. (2012). Analyzing multidimensional poverty in Guinea: a fuzzy set approach. AERC research paper 251, African Economic Research Consortium, Nairobi, Kenya.

Dinkelman, T., and Ranchhod, V. (2012). Evidence on the impact of minimum wage laws in an informal sector: domestic workers in South Africa. Journal of Development Economics, 99: 27-45.

Fapohunda, T.M., Atiku, S.O., and Lawal, I.O. (2013). Minimum wage implementation and management in a postrecession economy: the Nigerian experience. European Scientific Journal, 8(7): 18-35.

Foguel, M.N., Ramos, L., and Carneiro, F. (2001). The impacts of minimum wage on the labour market, poverty and fiscal budget in Brazil. texto para discussao No. 839, Institute of Applied Economic Research (IPEA), October 2001.

Gindling, T.H., and Terrell, K. (2005). The effect of minimum wages on actual wages in formal and informal sectors in Costa Rica. World Development, 33(11): 1905-1921.

Gindling, T.H., and Terrell, K. (2010). Minimum wages, globalization and poverty in Honduras. World Development, 38(6): 908-918.

Gindling, T.H. (2014). Does increasing the minimum wage reduce poverty in developing countries? IZA World of Labour 2014:30.

Greene, W.H. (2003). Econometric Analysis, (5th Ed), Pearson Education, Inc., USA.

Ham, A. (2013). Revisiting the effect of minimum wages in developing countries: evidence from a particular policy change in Honduras. University of Illinois at Urbana-Champaign.

Hansen, B.E. (2015). Econometrics, Department of Economics, University of Wisconsin.

Kapelyuk, S. (2014). Impact of minimum wage on income distribution and poverty in Russia. EERC working paper No 14/03, Economics Education and Research Consortium/GDN.

Neumark, D., Cunningham, W., and Siga, L. (2006). The effects of the minimum wage in Brazil on the distribution of family incomes: 1996 - 2001. Journal of Development Economics, 80:136-159.

Nwude, E.C. (2013). The politics of minimum wage in Nigeria: the unresolved issues. Asian Journal of Empirical Research, 3(4):477-492.

Okunmadewa, F.Y., Yusuf, S.A., and Omonona, B.T. (2007). Effects of social capital on rural poverty in Nigeria. Pakistan Journal of Social Sciences, 4(3): 331-339.

Omonona, B.T. (2009). Quantitative analysis of rural poverty in Nigeria. Nigeria Strategy Support Programme (NSSP) background paper No. 009, IFPRI/FGN, Abuja.

Oni, O.A., and Adepoju, T.A. (2014). Analysis of rural household well-being in Nigeria: a capability approach. International Journal of Social Economics, 41(9).

Oyekale, A.S., and Okunmadewa, F.Y. (2008). Fuzzy set approach to multidimensional poverty analysis in Abia State, Nigeria. Research Journal of Applied Sciences, 3(7):490-495.

Oyekale, T.O., Okunmadewa, F.Y. Omonona, B.T., and Oni, O.A. (2009). Fuzzy Set approach to multidimensional poverty decomposition in rural Nigeria. The Icfai Journal of Agricultural Economics, 6 (3\&4):7-44.

Oyekale, T.O. (2011). Impact of poverty reduction programmes on multidimensional poverty in rural Nigeria. Journal of Sustainable Development in Africa, 13(6):1-11.

Oyekale, T.O., and Oyekale, A.S. (2013). Assessment of multidimensional poverty in rural and urban Nigeria: evidence from Demographic and Health Survey (DHS). Journal of Human Ecology, 42(2):141-154.

Pauw, K., and Leibbrandt, M. (2012). Minimum wages and household poverty: general equilibrium macro-micro simulations for South Africa. World Development, 40(4):771-783.

Sabia, J.J. (2014). Minimum wages: a poor way to reduce poverty. Tax and Budget Bulletin No. 70, CATO Institute, March 2014.

Saget, C. (2001). Is the minimum wage an effective tool to promote decent work and reduce poverty? The experience of selected developing countries. Employment paper 2001/13, ILO (International Labour Office), Geneva. 
Salman, K.K. (2012). Do microenterprises reduce poverty in rural Nigeria? ARPN Journal of Agricultural and Biological Science, 7(6):421-429.

Sowunmi, F.A., Akinyosoye, V.O., Okoruwa, V.O., and Omonona, B.T. (2012). The landscape of poverty in Nigeria: a spatial analysis using senatorial districts-level data, American Journal of Economics, 5:61-74.

Staneva, A.V., and Arabsheibani, G.R. (2014). Is there an informal employment wage premium? evidence from Tajikistan, IZA Journal of Labour and Development 2014, 3:1.

Sugiyarto, G., and Endriga, B.A. (2008). Do minimum wages reduce employment and training? ERD working paper series No. 113, Asian Development Bank.

World Bank (2012). World Development Report 2013: Jobs. Washington DC: World Bank. DOI:10.1596/978-08213-9575. License: Creative Commons Attribution CC BY 3.0. 